\title{
Thinning as method to regulate sweet cherry crops - a review
}

\author{
Krzysztof Rutkowski ${ }^{1}$, Grzegorz Łysiak ${ }^{1, *}$ \\ 1 Department of Ornamental Plants, Dendrology and Pomology, Poznań University of Life Sciences; krzyszt- \\ of.rutkowski@up.poznan.pl \\ * Correspondence: glysiak@up.poznan.pl; Tel.: +48-848-79-46
}

\begin{abstract}
In perennial fruit crops, bearing can be influenced by various factors, including environmental conditions, germplasm, rootstocks, and cultivation methods. Cherries, one of the most important and popular fruit species from the temperate climate zone, achieve high prices on the market. New agricultural technologies and environmental factors force a change in the approach to cherry cultivation. Old-type cherry orchards with their high demand for water, nutrients and manual work are replaced by orchards of self-pollinating cherry cultivars grown on dwarf rootstocks. These changes make it necessary to search for ways to regulate fruiting, in particular to thin buds, flower and fruit. In view of environmental regulations and consumer pressure, thinning methods are being sought that either do not involve the use of chemicals or that use eco-friendly chemical agents. This review examines recent progress in understanding the effect of thinning methods on the physiology, tree growth and fruit quality of cherries, discusses horticultural practices aimed to ensure regular cropping and their influence on fruit quality, and provides suggestions for future research.
\end{abstract}

Keywords: fruit quality, pruning, growth regulation, fruit set, crop value

\section{Introduction}

Thinning is carried out regularly on stone fruit species such as peach and nectarine, but rarely on apricots, plums, sweet cherrier or sour cherries. However, in recent times, interest in the use of thinning has increased due to increased market requirements regarding the size and quality of fruit [1]. The response to and effectiveness of thinning depend not only on the species and cultivar, but also on climatic and soil conditions and agricultural treatments, especially pruning. Yield as well as vegetative growth are related to the intensity and timing of thinning [1].

Fruit trees produce a lot of flowers that they cannot turn into fruit and maintain until harvest. The number of flowers on a tree is very large and, depending on the species and size of tree, there may be up to 50,000 flowers per cherry tree and up to 20,000 flowers per peach tree [2]. In pome species, in order to obtain a good quality marketable crop, it is sufficient if only a few to about a dozen percent of flowers set fruit. For this reason, apple trees yield well already when $7 \%$ of flowers have set fruit. Stone fruit species require a higher level of pollination. In peach, sufficient yield is obtained when $25 \%$ of flowers set fruit [2], whereas sweet cherries yield well with the fruit setting ratio of $25-40 \%[3,4]$.

Rootstock strongly affects the number of flowers. Fruit trees grown on dwarf and semi-dwarf rootstocks set more flower buds [5]. However, cherry trees on dwarf rootstocks often bear an excessive number of small fruit with low sugar content [5]. Therefore, flower thinning is necessary to prevent over-yielding and to provide high-quality fruit $[6,7]$ in terms of the basic fruit quality parameters, such as size, colour, total soluble solids, and firmness [2].

The fruiting of trees is affected by a number of factors, which include environmental factors, such as tree nutrition, light and temperature. Often, however, endogenous factors are crucial, such as processes that regulate the initiation of flower buds. They take place 
during the summer and depend on the number of fruit on the tree. Fruit and developing seeds can, through the production of gibberellins, inhibit the initiation of flower buds and thus reduce the number of flowers in the next season [1].

Thinning is most often conducted with the use of chemicals. Chemical thinning reduces the workload compared to manual thinning and weakens the tendency to biannual bearing [2], a frequent feature of cross pollinated cultivars. However, the number of chemical compounds approved for thinning and for the protection of fruit plants is being constantly reduced in the EU. In addition, due to consumer pressure, retail chains are forcing the limitation of the number of permissible chemical treatments or the exclusion of certain active substances [8]. As manual thinning of cherries is very expensive due to the size of tree and the number of fruit, it is necessary to develop a chemical thinning technology that would be especially suitable for the treatment of abundantly fruiting self-pollinating cultivars [9].

The need for thinning sweet cherries is driven by the market - a higher market price is paid for larger fruit. The size of fruit is primarily a culitivar-specific feature, but is largely influenced by the number of fruit on the tree, and this depends, among other things, on the level of pollination resulting from weather conditions prevailing in the period of pollination and fertilization [1]. Although cherry is a cross-pollinated species, which can sometimes cause poor pollination, the more and more commonly cultivated self-pollinating cultivars set much more fruit than the cross-pollinated ones and thus require thinning for the fruit to meet the quality requirements [10]. Thinning improves crop quality in that it reduces fruit set in self-pollinating cherry cultivars, which set $10-15 \%$ more fruit than cross-pollinated cultivars $[11,12]$. Cherry trees produce a very large number of fruit per shoot compared to peaches or apples, but since the weight of the fruit/cm2 of the cross-sectional area of the trunk is low, thinning is physiologically justified.

Therefore, when fruit or flower bud set is high, early thinning can significantly increase the crop value. However, thinning of flowers or fruit of cherries [13], apricot, European plum, Japanese plum $[10,14,15]$ to regulate the size and to increase the crop value is only relevant in years of high yield, that is, when the number of buds or fruit set is very high. With a low yield, the fruit is naturally larger and of better quality. In addition, for stone fruit species it is advisable to use thinning of buds at a later stage so as to prevent excessively loaded branches from breaking $[10,14,15]$.

\section{Thinning Methods}

The decision on whether to use thinning and what thinning method to apply is made taking into account mainly the "orchard history", the previous year's yield, the environmental variables and the agronomic conditions [1]. All the methods discussed are summarised in Table 1.

\subsection{Pruning}

Pruning is one of treatments supporting the thinning of fruit. Its primary purpose is to control the tree size and to improve the distribution of light in the crown; however, proper pruning can also regulate the number of flower buds and reduce the need for thinning in the next growing season [16]. Different pruning systems are used depending on the species, cultivar, spacing, machine size and agronomic treatment. Also, pruning intensity and precision can vary and in some systems precise pruning is carried out to remove individual spurs or buds $[17,18]$.

However, pruning must always take into account the age of trees. When the orchard is young, the priority is to form a crown (shape and topological structure of a tree) to ensure continuity of production in subsequent years. At this stage, the type of growth and fruiting should be taken into account. Spur-bearing cultivars grafted on dwarf rootstocks have weak vigour and form few new shoots with a large number of fruit already in 
the first years of production. Such trees require more intensive thinning in the initial years to allow better and faster crown formation.

Pruning during the dormancy period may limit the number of flower buds, so it can be treated as the first stage of thinning. The advantage of pruning before the start of the vegetation season is that it enables the tree to maintain the assimilates accumulated in the branches, trunk and roots for the remaining buds, thus ensuring their better nourishment, which allows obtaining fruit with better quality parameters [9].

Pruning is often divided into two stages. In the first stage, the longest shoots are removed. This does not affect the yield in the event of temperature drops and the risk of damage to flower buds in the early spring period. The second cut is made when the risk of frost damage to flower buds has already passed. If only part of the flowers or flower buds freeze, it will cause them to thin out naturally, which can improve the quality of fruit and obtain a crop of higher commercial value [9].

The method and intensity of cutting is also determined by the rootstock used. Trees on vegetative rootstocks, such as Gisela ${ }^{\circledR} 6$ or Gisela ${ }^{\circledR} 12$, require different pruning compared to trees on strongly growing generative rootstocks, such as Mazzard (Prunus avium). Growers producing cherries on trees grown on a generative rootstock must limit tree growth and maintain or even increase fertility. However, when trees grow on dwarf vegetative rootstocks, a stronger focus should be placed on reducing a too high yield and, at the same time, on stimulating tree growth.

The removal of cherry shoots of small diameter during the dormant period allows the reduction of the total yield and obtaining larger fruit. This can be achieved by cutting $20 \%$ of all fruiting shoots each year. Shoots are not removed completely, but only shortened so as to leave stubs, because the best fruit is obtained on the youngest spurs at the base of last year's shoots. The length of stubs varies from 7-8 $\mathrm{cm}$ to $60 \mathrm{~cm}$ and depends on the location on the tree - the shortest stubs are near the tree top with their length increasing towards the bottom of the canopy. Strong apical dominance in cherries hinders the formation of lateral branches, which are necessary to produce the right number of leaves responsible for proper photosynthesis. Leaving stubs when pruning stimulates branching. This is especially important as the leaves on side shoots are up to $50 \%$ larger than the leaves on spurs. However, branching is not the only effect of shortening of annual shoots. Pruning annual shoots by $1 / 3$ to $1 / 2$ reduces yield in the next growing season, which can be considered as a special kind of thinning conducted at a very early stage. In addition, fruiting on shoots is not evenly distributed. The apical spurs (buds) are closer to each other and produce more flowers than the spurs at the base, growing on two-year-old shoots. Therefore, removing a third of new growth reduces the fruiting potential of the branches by about half [19].

Pruning can also negatively affect the physiology of the tree. This can happen when trees are pruned after harvest. Such timing of pruning has been recommended for a long time as it limits tree vigour, but it may lead to a lower availability of stored energy in the next season [20-22]. Such an effect is not observed after spring pruning. Also, thinning of flower buds before flowering reduces the yield, but does not increase the fruit size, the sugar content or the share of premium fruit. Studies indicate that to ensure proper fruit growth, the ratio of leaves to fruit in the summer should be 2:1 [23]. In addition to the leaf-to-fruit ratio, a good measure of tree nutrition is the leaf area per fruit. The fruit needs about $200 \mathrm{~cm} 2$ of leaf area to reach its maximum size. In such a case, the fruit size is not affected by thinning or chemical treatment [24]. Pruning of self-fertile cultivars on dwarf rootstocks during the dormant period or during flowering affects the fruit size, since this must have an impact on the above-mentioned leaf area per fruit ratio [25].

Pruning can be carried out by removing individual buds. Thinning of buds on spurs affects the fruit diameter to a smaller or larger extent, depending on cultivar. Fruit firmness increases with a decrease in yield. Fruit is significantly harder if only 1 bud is left per spur [24]. Removing 30\% of shoots and spurs improves the leaf-to-fruit ratio and the fruit size [26]. 


\subsection{Manual thinning}

Hand/Manual thinning may be economically unjustified due to the time and labor it requires [10]. However, it is the most accurate thinning method even if a large number of qualified employees is needed in a short time [27]. Manual thinning can be supported by a portable thinning machine (Effleureuse), which is an intermediate form between mechanical and manual thinning and makes the work more effective and considerably cheaper $[28,29]$.

Stone fruit species are thinned manually primarily during flowering. The disadvantage of thinning carried out at this time is that it is hardly selective. The advantage is that the early time of treatment improves the fruit size by reducing competition between generative and vegetative organs [30]. Thinning during flowering is associated with the risk of excessive yield limitation if frost occurs after flowering. This risk can be avoided by thinning after flowering; however, very late thinning may lead to the loss of assimilates, which can negatively affect fruit quality and reduce yield in both the current and subsequent growing season [1].

Hand removal of $20 \%$ of buds or $20 \%$ of flowers of 'Újfehértói Fürtös' cherry before or during flowering increased yield efficiency per unit of trunk cross-sectional area (TCSA). However, stronger thinning resulted in a decrease in yield, while fruit mass and diameter and total soluble solids increased linearly. The same study showed no significant differences in the average values of these quality parameters between fruit from trees thinned at bud and flower stages [31]. Also, experiments conducted on 'Summit' cherries grown on on Tables ${ }^{\circledR}$ Edabriz showed a significant increase in fruit weight after thinning cuts applied to fruiting spurs, whereas the best fruit size was obtained after removal of 30 to $50 \%$ of fruiting spurs [32]. Similar results were obtained by selective removal of reproductive buds from spurs, leaving one bud per spur. Thinning results were the best in the years of high crop load [13]. However, it should be remembered that the thinning effect is cultivar-dependent, because thinning of 15 to $50 \%$ of buds, spurs, flowers and fruit of the self-pollinating variety 'Lapins' grown on the bird cherry (Prunus avium L.) rootstock did not affect the yield. Nevertheless, 'Lapins' cherry thinning significantly reduced the share of fruit with a diameter of less than $21 \mathrm{~mm}$, i.e. below market standards [33]. Also other studies evidence that the reduction of the number of flower buds from the natural level ( 3 to 4 per spur) to 1 to 2 per spur resulted in a yield decrease to $25 \%$, while the average fruit size increased by $43 \%$. Soluble solids were found to have increased significantly as well, which proves that the leaf area per fruit ratio is a key factor here [34]. Another crucial variable determining the results of thining is the vigour of the rootstock and thus the whole tree as demonstrated by a study on the manual fruiting spur thinning of cherriers grown on the strongly growing rootstock 'Mazzard F-12/1'. The impact of thinning on fruit size was negligible, which is probably associated with a stronger vegetative than generative development of trees growing on this rootstock [35].

\subsection{Mechanical thinning of cherry flowers}

A gradual reduction of the use of chemical agents approved for thinning as well as a large amount of labour involved in manual thinning have resulted in an increased interest in mechanical thinning over the past 10-15 years. In addition, the use of chemicals may be ineffective due to its dependence on various internal and external factors (e.g. weather conditions). Also, the declining availability of manpower has made mechanical thinning an attractive alternative to both manual and chemical thinning [1]. This method reduces the time consumed by manual thinning by up to $85 \%$ [36]. The thinning device consists of a rod/spindle rotating on its axis with strings fixed to it, which can destroy part of the flowers on a tree [37]. However, in order to be effective, the use of a mechanical thinner requires a specific tree training system. Open and spindle crowns must be replaced by a hedgegrow system in which fruiting formations are exposed to mechanical devices $[5,35-45]$. The advantages of mechanical thinning are speed, independence from 
weather conditions, and suitability for ecological orchards. The only risk is tree infection through contact of pathogens with shoots and leaves damaged during the treatment [27].

Studies show that a portable flower thinning device can effectively remove flowers from apple trees and stone species, including cherries. Of all the device parameters evaluated, the spindle rotating speed had the greatest direct impact on the capacity to remove flowers. The device tested at the Washington State University Roza Research Orchard removed $61.1 \%$ of flowers (2500-3000 rpm), 30.8\% (1500-1800 rpm) and $18.0 \%$ (500-800 rpm) with a swipe of about $0.5 \mathrm{~m} \cdot \mathrm{s}-1$. In trees with a central leader, $50 \%$ of the flowers could be removed within $85 \mathrm{~s}$. The efficiency is also influenced by the speed [37] and weight [49] of the device. Research carried out in recent years has focused on the optimization of technical solutions (actuator, frame, string material characteristics, rotational speed, driving speed) adapted to the fruiting characteristics of different species and cultivars [50].

Experiments show that thinning efficiency also depends on the material used to knock off the flowers and the best results are achieved by using strings with the lowest bending stiffness. If the rotating speed of the thinning spindle is positively correlated with thinning efficiency depending on the string used, $50 \%$ of cherry flowers are removed by the thinner driving at a speed of $1 \mathrm{~m} / \mathrm{s}$ and a spindle speed of $\sim 240 \mathrm{rpm}$ [50]. The removal of about $40 \%$ of the flowers is sufficient to increase fruit weight and firmness [51].

Crop load regulation by removing flowers of e.g. apples, cherries and other stone fruit species, increases fruit size and generates higher returns for producers in most markets. The withdrawal of chemical thinning agents from the market or the need to re-register them, as well as the pressure of retail chains, have made mechanical thinning attractive. The advantage of mechanical thinning is that it can be applied to any trees trained to slim spindle system, regardless of the species, cultivar, air temperature and age of the trees. A noteworthy solution is also a combined method in which mechanical thinning is supplemented with chemical thinning. Mechanical thinning can prevent biennal bearing while reducing the labor costs required for manual thinning. In combination with chemical or manual thinning, it improves fruit quality [8].

\subsection{Chemical thinning}

Chemical thinning is much cheaper and faster than manual thinning not only because it involves significantly less workload compared to manual thinning [2] but also because standard plant protection equipment can be used to carry it out [27].

Chemical thinning involves the use of blossom desiccants, growth regulators and photosynthesis inhibitors. Dessicant agents, include e.g. fertilizers (ammonium thiosulfate (ATS), urea), and some sulfur compounds [52-55] [53]. They cause damage to the stigma and anthers, which prevents pollination [56]. Growth regulators, such as hydrogen cyanamide, interrupt dormancy, stimulate uniform development of flower buds, but also cause flower thinning if applied to flowering plants [57]. Other substances that have been found to be effective chemical thinners include herbicides or desiccants used in agricultural production [58,59] or oils of vegetable and animal origin. In the United States, research has been conducted on the use of cyanoamide, monocarbamide dihydrosulfate, pelargonic acid, endothalic acid and Tergitol TMN-6 as chemical thinning agents. In Europe, studies are carried out on the use of ammonium thiosulfate (ATS) and plant growth regulator 2-chloroethylphosphonic acid (ethephon), which are commonly applied to apple and pear trees during flowering [56,58-62]. The main objectives of the widespread use of thinning in the cultivation of apples and pears are to improve fruit quality and to prevent alternating bearing $[63,64]$.

Chemical thinning can be applied to stone fruits to a limited extent only [65]. The period during which chemical thinning can be carried out on cherries is shorter than for apples or pears, i.e. only during flowering or shortly thereafter [66]. The advantage is that the removal of flowers and buds in the initial period of growth increases assimilation, 
thereby reducing competition between the vegetative and generative organs of the tree. The result is stronger growth in the year of treatment, better fruit quality, increased yield and greater differentiation of flower buds responsible for flowering in the following year $[10,56]$.

Gibberellic acid inhibits the formation of flower buds in many pome species but also in stone species such as peaches, nectarines, cherries, apricots, plums and almonds [67]. Its use during the initiation of flower buds allows reducing the total number of flowers in the next growing season. The timing of application is important, since the development of buds can be influenced from full flowering to mid-season [63, 65-69]. One or two applications of gibberellic acid (GA3) can be carried out during endocarp lignification (first phase of fruit development) or when fruit colour changes from green to red (second phase of fruit development), whereas double GA3 application has been found to more effectively reduce flowering density and yield. Trees treated with two applications (50 and 100 mg.L-1) yield fruit with higher soluble solids, higher firmness and greater weight. Just like double spraying, a single application of two different gibberellic acids (GA3 and GA4+7) at a dose of $100 \mathrm{mg} \cdot \mathrm{L}-1$ also reduces flowering density. GA3 alone inhibits flowering more than GA4+7 even if both are applied at an equal dose $(200 \mathrm{mg}$. L-1).The simultaneous use of both acids additionally delays the flowering date by 4-5 days, improves fruit firmness, but does not affect fruit weight and total soluble solids. The application of growth hormones gives satisfactory results if it is correlated with the period of induction and differentiation of flowers specific to a given species and sometimes a cultivar $[73,74]$. Another hormone, cytokinin, can be used for fruitlet thinning. Cytokinin treatment is carried out after petal fall. However, it was found that cytokinin sprays had no effect on fruit size [24]. Other substances tested include molasses, California liquid, potassium soap, Tergitol, $2 \%-4 \%$ vegetable oil emulsion or copper $[28,52,75]$.

ATS is a popular agent used to thin apple and peach flowers. Its disadvantage is that it may have a phytotoxic effect on leaves, which in turn may reduce photosynthesis and reduce fruit size [54]. It has been reported that the use of $2 \%$ ATS does not cause visible signs of leaf damage [75]. However, at higher concentrations (3\%), ATS was found to cause visible phytotoxicity on leaves, and at lower concentrations ( 1 and $2 \%$ ), it did not reduce fruit set [6]. To reduce fruit set without damaging the leaves ATS can be applied twice at a concentration of $2 \%$, as shown in the study on 'Bing' cherries grown on 'Gisela 5 ' rootstock, which yielded less fruit of better quality after the treatment [75]. The timing of application is important - the best result was obtained by using ATS for the first time at $10 \%$ full bloom and again at $90 \%$ full bloom. In other studies, ATS effectively reduced cherry yield but did not improve fruit weight, fruit size, or content of titratable acids [54].

The phytotoxicity of chemical thinners can limit leaf carbon dioxide exchange. Young leaves were found to be more susceptible to leaf blade margin drying than older ones, but the leaves regenerated after the treatment $[75,76]$. The use of vegetable oil reduced mostly the leaf chlorophyll content (11\%) for 23 days and neither showed a thinning effect nor improved fruit quality. However, in another experiment, ATS, Californian liquid and tergitol reduced fruit set, improved fruit quality and size and allowed achieving a higher yield value. The use of Californian liquid resulted in a higher fruit diameter (24.2 mm - 23.2\% increase), whereas a maximum of $21.4 \mathrm{~mm}$ was achieved after tergitol and ATS treatments. Tergitol, ATS, and (lime sulfur) FOLS similarly increased total soluble solids and firmness [75].

The use of the gibberellin inhibitor, uniconazole, at 30\% full bloom reduced the fruit set of 'Bing' cherries. This shortened the time spent on manual thinning by about $50 \%$ and the crop load by about $40 \%$, and there was also a considerable shift to larger a fruit size $(>26 \mathrm{~mm})$, provided that the crop load was not too low. No negative effects on flowering and yield were observed in the following year [61]. Both mechanical and chemical treatments showed a strong thinning effect as well as an increase in fruit size, which, however, could only partially make up for the yield losses caused by thinning [28,29].

Another chemical thinner used for pome species is 2-chlorophosphonic acid (ethephon), but tests on cherries did not give positive results. Substances tested in recent 
years include the photosynthesis inhibitor metamitron (Brevis) and two naturally occurring compounds, abscisic acid (ABA) and 1-aminocyclopropane-1-carboxylic acid (ACC). However, the research is currently at an early stage and it is now hard to predict how effective they will be [45].

\section{The effect of the rootstock on thinning}

The use of dwarf rootstocks such as 'Gisela 5' and Tabel® Edabriz in the production of commodity cherries in the United States increased yield despite induced precocity and reduced tree vigour compared to the use of standard Mazzard rootstock. The increase in yield, however, resulted in smaller fruit, which was explained as due to indequate crop load management [34,52]. This effect was particularly acute in the cultivation of self-fertile cultivars such as 'Lapins', 'Sweethart' and 'Summit' [25,77]. The best solution used to improve the fruit size on trees growing on dwarf rootstocks was to remove of 30 to $50 \%$ of fruiting spurs [32]. Thinning can also be optimised by measuring the number of fruit to the branch cross-sectional area ratio. The best fruit quality was obtained with 10 cherries per $\mathrm{cm}^{2}$ of branch cross-sectional area [56,78]. The selection of the rootstock and thinning have a positive effect on many fruit quality parameters [63,79].

Rootstock, can affect the yield regardless of vigour [26], but the rule according to which higher yield is associated with smaller fruit is rootstock independent $[35,77,80,81]$. In a situation where the effectiveness of chemical thinning varies from year to year, a rational solution, especially for self-fertile cultivars, is the use of an appropriate rootstock that allows achieving acceptable yields of good quality cherries [52]. Comparative studies carried out on self-fertile 'Lapins' cherry trees showed that the highest yield per tree and yield efficiency with relatively large fruit (about $7 \mathrm{~g}$ ) were obtained on trees grown on $\mathrm{Gi}$ 154/7 and Gisela 4 rootstocks. Large cherries were harvested from trees growing on P-HL-A and Gi 523/02 rootstocks - 7.7 and $7.6 \mathrm{~g}$ respectively, but the total yield for the research period was significantly lower. Small fruit $(6.1 \mathrm{~g})$ and low yield were obtained on trees growing on the popular Gisela 5 dwarf rootstock [82]. Other studies show that the size of fruit from trees grafted on Gisela 5 depends on crop size and weather conditions $[83,84]$. Also, subsequent experiments with the use of various rootstocks indicate that in addition to the rootstock and cultivar, soil and climatic conditions are very important factors shaping the fruit quality $[85,86]$. Rootstock affects the number of bouquet buds and the number of flowers in the inflorescence [87]. The use of Gisela 5 dwarf rootstock significantly increased the number of flower buds compared to the more strongly growing Colt rootstock [88]. Also, a comparison of the Edabriz and F12/1 rootstocks indicated that the number of flowers and spurs on branches of trees grown on Edabriz was larger, whereas the size of fruit was smaller, than on trees grown on the strongly growing F12/1 [89].

\section{The impact of thinning on fruit quality}

Size is one of the most important fruit characteristics that consumers pay attention to and that affects the fruit's market value $[90,91]$. Fruit quality is directly related to the intensity of flower and fruit thinning. Studies show that an increase in yield is often accompanied by a smaller fruit size $[33,52,63,90]$. The response to thinning depends on the age of the tree, the quality of flower buds, the competition between flowers in the inflorescence and the tree crown, and the timing of the procedure. Also, the order in which flower buds open on shoots can indirectly affect protection against frost and, at the same time, the effectiveness of thinning. Buds on short shoots generally develop faster than those on long shoots, and therefore, it is advisable to thin short shoots if there is a risk of frost. On the other hand, delayed thinning may cause that mainly buds on weak long shoots, which flower latest, will be removed. In addition, treatment delay affects vegetative growth and differentiation of flower buds for the next year [69]. Fruit on short shoots (less than $25 \mathrm{~cm}$ ) reach smaller sizes, because those shoots have too many flower buds 
and too few leaves to produce fruit of the right size. Therefore, in order to improve the fruit size in cultivars that produce a large number of short shoots, shoots should be headed back so as to leave only one bud $[25,26,78,92]$. Such thinning intensity improves the fruit size, coloration, firmness and content of sugars and acids [13,92].

The effect of thinning on quality parameters also depends on the cultivar. A high crop load and a thinning treatment carried out 6-8 weeks after flowering caused a significant decrease in fruit size of 'Sweetheart' cherries, but there was no decrease in fruit diameter when thinning was conducted earlier. The date of thinning also affected firmness and TSS (Total Soluble Solids) concentration; for example, no reduction in fruit acidity was observed in fruit from trees thinned immediately after flowering [78]. The size of fruit is also associated with greater availability of assimilates during the period of cell division, which occurs up to 11 days after flowering. Later, the fruit grows only as a result of an increase in the volume of cells $[93,94]$. Thinning after flowering increases the susceptibility of fruit to cracking at lower crop load levels [95].

As consumers prefer large cherries, new cherry cultivars should be able to bear fruit with a minimum diameter of $25 \mathrm{~mm}$. According to consumer expectations, new cherry cultivars introduced to the market should have a weight of 11-13g, a diameter of 29-30 $\mathrm{mm}$, TSS of $17-19 \%$, firmness of 70-75 and juice $\mathrm{pH}$ of 3.8 [96].

Thinning of flowers and spurs increases the share of fruit with a diameter over 25.5 $\mathrm{mm}$ [63]. Fruit from two-year-old spurs has been found to have higher TSS compared to fruit from other tree fruiting parts [97].

Thinning significantly increases not only the fruit size, but also the level of TSS and anthocyanins, and the total antioxidant capacity of seeds. Hence the opinion that thinning can increase the organoleptic and nutraceutical properties of cherries [79]. A higher leaf area-to fruit ratio results in a higher fruit mass, a darker fruit colour, a higher TSS, a higher ratio of sugars to acids. and earlier fruit ripening [98]. Also, the content of glucose, fructose and sorbitol, the sum of individual sugars and the content of malic acid differed significantly depending on the thinning treatment. By contrast, a low leaf area-to-fruit ratio may prolong the ripening process [98].

Years with high rainfall are associated with the problem of fruit cracking, which is cultivar specific. Studies of the relationship between crop load and the incidence of cracking have shown a negative correlation. The cracking tendency can be determined, but only after the end of cell division. Fruit width has been observed to be positively correlated with cuticular cracking, but contrary to what has been maintained in literature, the relationship between the concentration of soluble sugars or firmness and the indicence of cracking is low and debatable. It seems that the decisive factors, in addition to the genetic propensity of the cultivar, are crop load and fruit size [95].

As discussed above, flower bud thinning can regulate the fruit-to-leaf area ratio on trees grown on dwarf rootstocks. This ratio influences the yield, fruit quality and vigour of trees, but it has no effect on the whole canopy net CO2 exchange rate (NCER canopy), which indicates that it does not affect the intensity of photosynthesis. According to the results obtained at Michigan State University, NCER canopy and net assimilation are more strongly determined by weather and sun altitude. Trees thinned to $20 \mathrm{fruit} / \mathrm{m} 2$ of leaf area had yield reduced by $68 \%$, but higher fruit weight $(+25 \%)$, higher firmness $(+25 \%)$, higher soluble solids $(+20 \%)$ and fruit diameter $(+14 \%)$ compared to unthinned (control) trees (84 fruit/m2). In the same study, the flower-to-leaf ratio did not affect the subsequent induction of flower buds, although the fruit-to-leaf area ratio influenced the growth in the second part of summer [99].

Studies assessing the effects of thinning with ATS on the fruit quality of three self-sterile or partially self-sterile cultivars ('Blaze Star", 'Samba', 'Techlovan') were conducted in Germany. Thinning efficiency was not dependent on the ATS concentration used. The treatments had no effect on fruit weight and anthocyanin content, but resulted in an increase in total soluble solids and $\mathrm{pH}$ value of the juice [100].

Thinning tests were also carried out with limestone sulfur and the fungicide Netzschwefel Stulln (in which the active substance is soluble sulfur in the form of micro 
granules), but no visible results were achieved. The only positive outcome of the application was lower flower infestation by Monilinia laxa. [28,29].

\section{The effect of thinning on yield}

Thinning may affect the yield $[49,51,78,101]$. The use of sulfur lime (FOLS) as a thinning agent on the self-fertile 'Bing'/Gisela®5 cultivar reduced the yield by up to $40 \%$ $[53,75,99]$. The application of ATS to thin flowers of the cross-pollinated 'Regina' cherry on the 'Gisela 5 ' rootstock resulted in a yield decrease by $29.4 \%$ at $20 \mathrm{~g}$ ATS, by $43.0 \%$ at $30 \mathrm{~g}$ ATS and by $48.9 \%$ at $40 \mathrm{~g}$ ATS [56] . In another study, manual thinning of the spurs, flower buds or flowers of the self-fertile 'Lapins' cherry trees improved the fruit quality without reducing the yield [33]. Another parameter evaluated by researchers is crop value, which varies depending on fruit quality. Crop value increased after ATS and FOLS chemical thinning of 'Bing' cherries [52] and after thinning of flowers of 'Bing' cherry trees grown on the Gisela 5 rootstock. The same was observed for 'Sweetheart'cherries grafted on the 'Mazzard' rootstock, where the removal of 50\% of flower buds increased the crop value [13]. By contrast, thinning of flowers and spurs of Gisela 6-rooted trees caused a decrease in crop value [63].

\section{The effect of thinning on vegetative growth}

The indicators most commonly used to measure vegetative growth are the trunk cross-sectional area, the average and total shoot length, and indicators based on leaf surface. In cherries, shoot length is positively correlated with leaf surface [97], whereas shoot growth is negatively correlated with crop size [13].

The vigour of cherry trees decreases with increasing yield [102]. High cropping trees have reduced shoot growth and leaf area compared to non-blooming trees [103]. In a study on 'Lapins' cherries grafted on the rootstock 'Mazzard F-12/L, spur thinning reduced leaf area, but only if the percentage of removed fruiting spurs was above $50 \%$. Removing $50 \%$ of spurs or less did not affect the overall leaf area on the tree. This is probably due to a larger leaf area in combinations where thinning was used. By contrast, the removal of $75 \%$ of spurs resulted in leaf area reduction, whereas it did not affect shoot length [35]. A high fruit-to-leaf area ratio reduces shoot length, but does not affect leaf surface. The shoot growth rate in the initial 40-50 days of the growing season depends on the reserves stored in the lignified organs of the tree. The shoot growth rates are highest near the oneset of phase III of fruit development, i.e. 49-60 days after flowering, and decrease later. In the post-harvest period, shoot length increase by only 15\% [99].

\section{The effect of thinning on physiological processes}

Thinning, especially chemical thinning, is a serious interference with plant physiological processes. The use of chemicals, especially desiccants, may lead to leaf damage [29], which forces the plant to regenerate and repair injuries, causing the consumption of stored reserves.

However, at the initial stage of fruit growth, assimilates are supplied from reserves accumulated in wood, and not from developing leaves. Therefore, it is assumed that the use of desiccant agents, also those damaging the leaves, will not have a significant impact on fruit set $[29,52]$. Later, however, fruit is nurtured by compounds produced by photosynthesis in leaves, which is reflected in the level of carbohydrates - leaves of non-fruiting cherry trees were found to have a higher concentration of carbohydrates compared to fruit-bearing ones [104]. The distribution of assimilates is also affected by the removal of a part of spurs in the dormancy period. Such prunning improves the distribution of assimilates among a smaller numer of fruit, and thus can ensure a better balance between growth and fruiting [105].

Thinning has been found to influence the mineral composition of leaves. Hand thinning of flowers improves the absorption and content of nutrients. Thinning of cherry 
flowers affects the seasonal changes in the absorption of micro and macroelements in cherries. The content of nutrients in leaves differed significantly between treatments carried out before, during and after fruit ripening [106].

Photosynthetic activity can be monitored by measuring leaf gas exchange. It has been observed that leaf gas exchange is reduced after thinning. This is because it takes some time for leaves to regenerate after treatment. Among trees thinned with desiccant agents, the leaves of trees thinned with ATS regenerated the fastest, and ATS reduced gas exchange only slightly [75]. However, it should be noted that phytotoxicity of desiccant agents, such as ATS, depends on the course of weather conditions during treatment [29].

Oil-based preparations used for thinning may also have negative side effects, such as choking of stomata, which limits leaf gas exchange and increases intercellular carbon dioxide concentration thus resulting in plant stress [107]. Phytotoxic activity manifest in leaf burn was observed on trees treated with ATS, tergitol, and fish oil mixed with California liquid. Those substances probably damage the structure of photosystem 2 and the thylakoid membrane [76,108], and consequently reduce fluorescence (Fv), gas exchange (NCER) and stomatal conductance (gs) [76]. Young, developing leaves are more vulnerable to damage, so thinning agents hinder photosynthesis in those leaves to a larger extent than in mature leaves. This is likely due to yet unfully developed ablility to photosynthesize, unripe stomata [109], and higher absorption of thinning preparation by the tender epidermis [75].

Some thinners damage the photosynthetic complex absorbing light and increase energy dispersion through non-photochemical processes [110,111]. A similar fluorescence reduction was observed in several tree species in response to foliar application of salt [110]. Treatments with fish oil combined with California liquid (FOLS) after flowering did not affect fluorescence but significantly lowered the efficiency of photosystem 2 (ФPSII) [76].

Thinners may also slow down the formation of chlorophyll in leaf tissues. Chemical thinning was observed to reduce chlorophyll content by $6-19 \%$ percent. The increase in SPAD values (chlorophyll content) after chemical thinning is positively correlated with the increase in leaf NCER (CO2 exchange rate) [75], which proves that lower chlorophyll content is a factor limiting photosythesis in young leaves [112].

\section{Conclusons}

There is an increasing trend towards growing self-fertile cherry cultivars, which set more fruit of smaller size. On the other hand, the market favours large fruit, but at the same time high yields must be obtained to ensure the profitability of production. Chemical thinning methods differ in terms of effectiveness and phytotoxicity. Therefore other methods must be sought that can be used even 2-3 weeks after flowering to obtain optimal treatment results. Also research and development work is necessary to devise new thinning tools and methods, including those for mechanical thinning. It is also important to design a method that would reconcile a large fruit size a high crop load. Experiments assessing the number and location of fertilized fruit are especially welcome in this context. Another research direction is to study the limitation of photosynthesis up to 3 weeks after flowering to allow the dropping of excess fruit without damaging leaves or fruit that remains on the tree. A significant aspect is also the determinng of economic benefits of bud, flower or fruitlet thinning taking into account thinning intensity levels and time of treatment.

Table 1. Summary of experimental methods of thinning cherries

\begin{tabular}{ccc}
\hline Method of thinning & Chemical substance & Reference \\
\hline \multirow{2}{*}{ Desiccant agents } & Chemical & \\
& ATS, & {$[6,28,29,52,54,56,75,76,100]$} \\
& wettable sulphur, & {$[28,29]$}
\end{tabular}




$\begin{array}{cl}\text { lime sulphur, } & {[28,29]} \\ \text { potassium soap, } & {[28,29]} \\ \text { copper } & {[28,29]}\end{array}$

\begin{tabular}{|c|c|c|}
\hline Surfactant & Tergitol, surfactant Maxx ${ }^{\mathrm{TM}}$ & $\frac{16,75,76,113,114]}{2}$ \\
\hline Growth regulators & $\begin{array}{c}\text { GA3, GA4+7, } \\
\text { hydrogen cyanamide }\end{array}$ & $\begin{array}{c}{[73,102]} \\
{[115-117]}\end{array}$ \\
\hline
\end{tabular}

\begin{tabular}{ccc}
\hline & Uniconazole & {$[61]$} \\
Growth retardant & (E-1-(4-chlorophenyl)-4,4-dimethy & \\
& 1-2-(1,2,4-triazol-1-yl-1-penten-3-ol & \\
\hline \multirow{2}{*}{ Oil } & fishoil + 2.5\% lime sulphur (FOLS) & {$[52,53,75,76]$} \\
& vegetable oil emulsion (VOE), & {$[52,75,76]$} \\
& rapeseed oil & {$[6]$} \\
\hline \multirow{2}{*}{ Other } & whey & {$[29]$} \\
& vinasse, & {$[29]$} \\
\hline & Mechanical & {$[6,13,16,33,34,78,79,97,99]$} \\
& removal of buds & {$[28,29,31,33,63,78,106]$} \\
Pruning & Removal of flowers & {$[26]$} \\
& removal of short shoots & {$[26,33,35,63,105]$} \\
& removal of spurs & {$[29,101]$} \\
& Removal of fruit & {$[78]$} \\
\hline Mechanical & Removal of fruitlets & {$[47,118-120]$} \\
\hline Hand-held & & {$[28,29,49-51,121]$} \\
\hline
\end{tabular}

Author Contributions: Both autors contributed equaly to the paper. All authors have read and agreed to the published version of the manuscript.

Funding: The publication was co-financed within the framework of the "Regional Initiative Excellence" programme implemented at the initiative of the Polish Ministry of Science and Higher Education in 2019-2022 (No. 005/RID/2018/19)", financing amount: PLN 12,000,000.

Conflicts of Interest: The authors declare no conflict of interest.

\section{References}

1. Costa, G.; Botton, A.; Vizzotto, G. Fruit Thinning: Advances and Trends. In Horticultural Reviews; Warrington, I., Ed.; John Wiley \& Sons, Inc.: Hoboken, NJ, USA, 2018; pp. 185-226 ISBN 978-1-119-52108-2.

2. Costa, G.; Blanke, M.M.; Widmer, A. Principles of Thinning in Fruit Tree Crops - Needs and Novelties. Acta Hortic. 2013, 17-26, doi:10.17660/ActaHortic.2013.998.1.

3. Wojcik, P.; Wojcik, M. Effect of Boron Fertilization on Sweet Cherry Tree Yield and Fruit Quality. Journal of Plant Nutrition 2006, 29, 1755-1766, doi:10.1080/01904160600897471.

4. Beyhan, N.; Karakaş, B. Investigation of the Fertilization Biology of Some Sweet Cherry Cultivars Grown in the Central Northern Anatolian Region of Turkey. Scientia Horticulturae 2009, 121, 320-326, doi:10.1016/j.scienta.2009.02.028.

5. $\quad$ Łysiak, G.P.; Kurlus, R. Rootstock Effect on Optimum Harvest Date and Storability of Two Apple Cultivars. In Proceedings of the Proc. Int. Conf. Fruit Production and Fruit Breeding; 2000; pp. 12-13.

6. Milić, B.; Keserović, Z.; Dorić, M.; Ognjanov, V.; Magazin, N. Fruit Set and Quality of Self-Fertile Sweet Cherries as Affected by Chemical Flower Thinning. Horticultural Science 2015, 42, 119-124, doi:10.17221/288/2014-HORTSCI. 
7. Davis, K.; Stover, E.; Wirth, F. Economics of Fruit Thinning: A Review Focusing on Apple and Citrus. HortTechnology 2004, 14, 282-289, doi:10.21273/HORTTECH.14.2.0282.

8. Seehuber, C.; Damerow, L.; Kunz, A.; Blanke, M.M. Selective Mechanical Thinning for Crop Load Management (CLM) of Fruit Trees. Acta Hortic. 2014, 405-410, doi:10.17660/ActaHortic.2014.1058.49.

9. Byers, R.E.; Costa, G.; Vizzotto, G. Flower and Fruit Thinning of Peach and Other Prunus. Hortic Rev 2010, 28, 351.

10. Byers, R.E.; Costa, G.; Vizzotto, G. Flower and Fruit Thinning of Peach and Other Prunus. In Horticultural Reviews; John Wiley \& Sons, Ltd, 2003; Vol. 28, pp. 351-392 ISBN 978-0-470-65085-1.

11. Choi, C.; Andersen, R.L. Variable Fruit Set in Self-Fertile Sweet Cherry. Can. J. Plant Sci. 2001, 81, 753-760, doi:10.4141/P00-161.

12. Lech, W.; Malodobry, M.; Dziedzic, E.; Bieniasz, M.; Doniec, S. Biology of Sweet Cherry Flowering. J. Fruit Ornam. Plant Res. 2008, 16, 189-199.

13. Einhorn, T.C.; Laraway, D.; Turner, J. Crop Load Management Does Not Consistently Improve Crop Value of 'Sweetheart'/'Mazzard' Sweet Cherry Trees. HortTechnology 2011, 21, 546-553, doi:10.21273/HORTTECH.21.5.546.

14. Webster, A.D.; Andrews, L. Fruit Thinning Victoria Plums ( Prunus Domestica L.): Preliminary Studies with Paclobutrazol. Journal of Horticultural Science 1985, 60, 193-199, doi:10.1080/14620316.1985.11515618.

15. Webster, A.D.; Andrews, L. Flower and Fruit Thinning of Victoria Plum (Prunus Domestica L.) with Paclobutrazol. Acta Hortic. 1986, 703-704, doi:10.17660/ActaHortic.1986.179.119.

16. Robinson, T.; Hoying, S.; Sazo, M.M.; Rufato, A.D. Precision Crop Load Management Part 2. N.Y. Fruit Quart. . 2014, 9-13.

17. Lauri, P.E.; Lespinasse, J.M. The Vertical Axis and Solaxe Systems in France. Acta Hortic. 1998, 287-296, doi:10.17660/ActaHortic.1998.513.34.

18. Robinson, T.L.; Dominguez, L.I.; Acosta, F. Pruning Strategy Affects Fruit Size, Yield and Biennial Bearing of 'Gala' and 'Honeycrisp' Apples. Acta Hortic. 2016, 257-264, doi:10.17660/ActaHortic.2016.1130.38.

19. Long, L. Four Simple Steps to Pruning Cherry Trees on Gisela and Other Productive Rootstocks. 2007.

20. Conesa, M.R.; Martínez-López, L.; Conejero, W.; Vera, J.; Ruiz-Sánchez, M.C. Summer Pruning of Early-Maturing Prunus Persica: Water Implications. Scientia Horticulturae 2019, 256, 108539, doi:10.1016/j.scienta.2019.05.066.

21. Ikinci, A.; Kuden, A.; Ak, B. Effects of Summer and Dormant Pruning Time on the Vegetative Growth, Yield, Fruit Quality and Carbohydrate Contents of Two Peach Cultivars. African Journal of Biotechnology 2013, 13, 84-90, doi:10.5897/AJB09.1614.

22. Rutkowski, K.; Zydlik, Z.; Stachowiak, A. Effect of Tree Pruning Intensity on the Content of Mineral Components in the Sour Cherry Leaves of 'Eutówka.' Folia Horticulturae 2018, 30, doi:10.2478/fhort-2018-0005.

23. Lang, G.A. Underlying Principles of High Density Sweet Cherry Production. Acta Hortic. 2005, 325-336, doi:10.17660/ActaHortic.2005.667.47.

24. Reginato, G.H.; Robinson, T.L.; Yoon, T.M. Crop Regulation and Cytokinin Sprays to Improve "Sweetheart" Sweet Cherry Fruit Size. Acta Hortic. 2011, 849-856, doi:10.17660/ActaHortic.2011.903.118.

25. Reginato, G.H.; Robinson, T.L.; Yoon, T.M. Improving Cherry Fruit Size of Self-Fertile Cultivars in NY Orchards. New York Fruit Quartetly 2008, 16, 27-30.

26. Robinson, T.L.; Bujdosó, G.; Reginato, G. Influence of Pruning Severity on Fruit Size of "Sweetheart", "Lapins" and "Hedelfingen" Sweet Cherry Grown on Gisela Rootstocks. Acta Horticulturae 2014, 1020, 441-452, doi:10.17660/ActaHortic.2014.1020.61. 
27. Costa, G.; Botton, A.; Vizzotto, G. Fruit Thinning: Advances and Trends. Hortic. Rev 2018, 46, 185-226.

28. Spornberger, A.; Leder, L.; Böck, K.; Keppel, H.; Modl, P. Auswirkungen von Ausdünnungsmaßnahmen auf Ertragsparameter, Krankheitsbefall und Fruchtqualität von Süßkirschen (Prunus avium L.) unter ökologischen Anbaubedingungen. Erwerbs-Obstbau 2011, 53, 15-22, doi:10.1007/s10341-011-0126-7.

29. Böck, K.; Leder, L. Thinning in Sweet Cherries (Prunus Avium L.) in Organic Farming- Impact on Vegetative and Generative Parameters as Well as Fruit Quality (German), 2010.

30. Byers, R.E. Response of Peach Trees to Bloom Thinning. Acta Hortic. 1989, 125-132, doi:10.17660/ActaHortic.1989.254.18.

31. Davarynejad, G.H.; Nyéki, J.; Szabó, T.; Szabó, Z. Influences of Hand Thinning of Bud and Blossom on Crop Load, Fruit Characteristics and Fruit Growth Dynamic of Újfehértói Fürtös Sour Cherry Cultivar. Am-Euras. J. Agric. E Environ. Sci. 2008, 4, 138-141.

32. Lauri, P.E.; Claverie, J. Sweet Cherry Training to Improve Fruit Size and Quality - An Overview of Some Recent Concepts and Practical Aspects.; Acta Hort., 2005; Vol. 667.

33. von Bennewitz, E.; Sanhueza, S.; Elorriaga, A. Effect of Different Crop Load Management Strategies on Fruit Production and Quality of Sweet Cherries (Prunus Avium L.) 'Lapins' in Central Chile. Journal of Fruit and Ornamental Plant Research 2010, 18, 51-57.

34. Lang, G.A.; Ophardt, D.R. Intensive Crop Regulation Strategies in Sweet Cherries. In Proceedings of the XXV International Horticultural Congress, Part 4: Culture Techniques with Special Emphasis on Environmental Implications 514; 1998; pp. 227-233.

35. Ayala, M.; Andrade, M.P. Effects of Fruiting Spur Thinning on Fruit Quality and Vegetative Growth of Sweet Cherry (Prunus Avium). CIENCIA E INVESTIGACIÓN AGRARIA 2009, 36, 443-450.

36. Overbeck, V.; Blanke, M.M.; Schmitz, M. Modern Training Systems for Forcing Sweet Cherries - Slender Spindle or Hedgerow for Protected Growing? Acta Hortic. 2019, 657-662, doi:10.17660/ActaHortic.2019.1242.97.

37. Meng Wang; Hui Wang; Qin Zhang; Karen M. Lewis; Patrick A. Scharf A Hand-Held Mechanical Blossom Thinning Device for Fruit Trees. Applied Engineering in Agriculture 2013, 29, 155-160, doi:10.13031/2013.42646.

38. Damerow, L.; Kunz, A.; Blanke, M. Mechanische Fruchtbehangsregulierung. Erwerbs-Obstbau 2007, 49, 1-9, doi:10.1007/s10341-007-0029-9.

39. Damerow, L.; Blanke, M.M. A Novel Device for Precise and Selective Thinning in Fruit Crops to Improve Fruit Quality. Acta Hortic. 2009, 275-280, doi:10.17660/ActaHortic.2009.824.32.

40. Baugher, T.A.; Schupp, J.; Ellis, K.; Remcheck, J.; Winzeler, E.; Duncan, R.; Johnson, S.; Lewis, K.; Reighard, G.; Henderson, G.; et al. String Blossom Thinner Designed for Variable Tree Forms Increases Crop Load Management Efficiency in Trials in Four United States Peach-Growing Regions. HortTechnology 2010, 20, 409-414, doi:10.21273/HORTTECH.20.2.409.

41. Solomakhin, A.A.; Blanke, M.M. Mechanical Flower Thinning Improves the Fruit Quality of Apples: Flower Thinning Improves Apple Quality. J. Sci. Food Agric. 2010, 90, 735-741, doi:10.1002/jsfa.3875.

42. Miller, S.S.; Schupp, J.R.; Baugher, T.A.; Wolford, S.D. Performance of Mechanical Thinners for Bloom or Green Fruit Thinning in Peaches. HortScience horts 2011, 46, 43-51, doi:10.21273/HORTSCI.46.1.43.

43. Schupp, J.R.; Baugher, T.A. Peach Blossom String Thinner Performance Improved with Selective Pruning. horts 2011, 46, 1486-1492, doi:10.21273/HORTSCI.46.11.1486.

44. Basak, A.; Juraś, I.; Wawrzyńczak, P.; Blanke, M.M. Environmental-Friendly Thinning in Apple by Use of the "Baum" Device, Alone or Combined with Benzyladenine at Reduced Rate. Acta Hortic. 2013, 43-50, doi:10.17660/ActaHortic.2013.998.4. 
45. Greene, D.; Costa, G. Fruit Thinning in Pome- and Stone-Fruit: State of the Art. Acta Hortic. 2013, 93-102, doi:10.17660/ActaHortic.2013.998.10.

46. Seehuber, C.; Damerow, L.; Blanke, M.M. Concepts of Selective Mechanical Thinning in Fruit Tree Crops. Acta Hortic. 2013, 77-83, doi:10.17660/ActaHortic.2013.998.8.

47. Asteggiano, L.; Giordani, L.; Bevilacqua, A.; Vittone, G.; Pellegrino, S.; Costa, G. Bloom Mechanical Thinning Improves Fruit Quality and Reduces Production Cost in Peach. Acta Hortic. 2015, 389-394, doi:10.17660/ActaHortic.2015.1084.55.

48. Kon, T.M.; Schupp, J.R.; Winzeler, H.E.; Marini, R.P. Influence of Mechanical String Thinning Treatments on Vegetative and Reproductive Tissues, Fruit Set, Yield, and Fruit Quality of 'Gala' Apple. horts 2013, 48, 40-46, doi:10.21273/HORTSCI.48.1.40.

49. Lopes, M.; Gaspar, P.D.; Simões, M.P. Current Status and Future Trends of Mechanized Fruit Thinning Devices and Sensor Technology. 2019, doi:10.5281/ZENODO.3607801.

50. Meng Wang; Qin Zhang; Karen M Lewis Parametric Study of Hand-Held Mechanical Bloom Thinner in Cherry Orchards. In Proceedings of the 2013 Kansas City, Missouri, July 21 - July 24, 2013; American Society of Agricultural and Biological Engineers, 2013.

51. Spornberger, A.; Buvac, D.; Hajagos, A.; Leder, L.; Böck, K.; Keppel, H.; Vegvari, G. Impact of a Mechanical Flower Thinning on Growth, Yield, Diseases and Fruit Quality of Sweet Cherries (Prunus Avium L.) under Organic Growing Conditions. Biological Agriculture $\mathcal{E}$ Horticulture 2014, 30, 24-31, doi:10.1080/01448765.2013.844079.

52. Whiting, M.D.; Ophardt, D.; McFerson, J.R. Chemical Blossom Thinners Vary in Their Effect on Sweet Cherry Fruit Set, Yield, Fruit Quality, and Crop Value. HortTechnology 2006, 16, 66-70, doi:10.21273/HORTTECH.16.1.0066.

53. Lenahan, O.M.; Whiting, M.D. Fish Oil plus Lime Sulfur Shows Potential as a Sweet Cherry Postbloom Thinning Agent. HortScience 2006, 41, 860-861, doi:10.21273/HORTSCI.41.3.860.

54. Schoedl, K.; Denk, A.; Hummelbrunner, S.; Modl, P.; Forneck, A. No Improvement in Fruit Quality through Chemical Flower Thinning in Sweet Cherry (Prunus Avium L.). Journal of the Science of Food and Agriculture 2009, 89, 1236-1240.

55. Rasouli, M.; Khademi, O.; Asadi, W. The Impact of New Blossom Thinners and Hand-Thinned on Fruit Quality and Quantity in Peach Cv. Alberta and Nectarine Cv. Sun King. International Journal of Fruit Science 2020, 20, 1238-1254, doi:10.1080/15538362.2020.1717404.

56. Kurlus, R.; Rutkowski, K.; Łysiak, G.P. Improving of Cherry Fruit Quality and Bearing Regularity by Chemical Thinning with Fertilizer. Agronomy 2020, 10, 1281, doi:10.3390/agronomy10091281.

57. Powell, A. Peaches - Dormex Application Information 1999.

58. Fallahi, E. Applications of Endothalic Acid, Pelargonic Acid, and Hydrogen Cyanamide for Blossom Thinning in Apple and Peach. HortTechnology 1997, 7, 395-399.

59. Fallahi, E.; Rom, C.R.; Fallahi, B. Effects of Hydrogen Cyanamide, Ammonium Thiosulfate, Endothalic Acid, and Sulfcarbamide on Blossom Thinning, Fruit Quality, and Yield of Apples. Journal of the American Pomological Society 2006, 60, 198.

60. González-Rossia, D.; Reig, C.; Juan, M.; Agustí, M. Horticultural Factors Regulating Effectiveness of GA3 Inhibiting Flowering in Peaches and Nectarines (Prunus Persica L. Batsch). Scientia Horticulturae 2007, 111, 352-357, doi:10.1016/j.scienta.2006.11.001.

61. Stern, R.A.; Raz, A.; Goldway, M. The Growth Retardant Uniconazole Is an Effective Blossom Thinner for “Bing” Cherry (Prunus Avium). Acta Hortic. 2014, 513-519, doi:10.17660/ActaHortic.2014.1020.69. 
62. Fallahi, E.; Greene, D.W. The Impact of Blossom and Postbloom Thinners on Fruit Set and Fruit Quality in Apples and Stone Fruits. In Proceedings of the XI International Symposium on Plant Bioregulators in Fruit Production 884; 2009; pp. 179-187.

63. Whiting, M.D.; Ophardt, D. Comparing Novel Sweet Cherry Crop Load Management Strategies. HortScience 2005, 40, 1271-1275.

64. Tromp, J. Flower-Bud Formation in Pome Fruits as Affected by Fruit Thinning. Plant Growth Regulation 2000, 31, 27-34, doi:10.1023/A:1006342328724.

65. Schupp, J.R.; Auxt Baugher, T.; Miller, S.S.; Harsh, R.M.; Lesser, K.M. Mechanical Thinning of Peach and Apple Trees Reduces Labor Input and Increases Fruit Size. HortTechnology hortte 2008, 18, 660-670, doi:10.21273/HORTTECH.18.4.660.

66. Wertheim, S.J. Developments in the Chemical Thinning of Apple and Pear. Plant Growth Regulation 2000, 31, 85-100, doi:10.1023/A:1006383504133.

67. Pharis, R.P.; King, R.W. Gibberellins and Reproductive Development in Seed Plants. Annu. Rev. Plant. Physiol. 1985, 36, 517-568, doi:10.1146/annurev.pp.36.060185.002505.

68. Intrieri, C.; Sansavini, S. Ricerche Sul Controllo Della Differenziazione Delle Gemme Nel Pesco « Southland » Mediante l'acido Gibberellico. Rivista di ortoflorofrutticoltura italiana 1972, 56, 433-447.

69. Byers, R.E.; Carbaugh, D.H.; Presley, C.N. The Influence of Bloom Thinning and GA3 Sprays on Flower Bud Numbers and Distribution in Peach Trees. Journal of Horticultural Science 1990, 65, 143-150, doi:10.1080/00221589.1990.11516040.

70. Southwick, S.M.; Yeager, J.T. Effects of Postharvest Gibberellic Acid Application on Return Bloom of "Patterson" Apricot. Acta Hortic. 1991, 459-466, doi:10.17660/ActaHortic.1991.293.54.

71. Southwick, S.M.; Jr., R. Commercial Chemical Thinning of Stone Fruit in California by Gibberellins to Reduce Flowering. Acta Hortic. 1995, 135-148, doi:10.17660/ActaHortic.1995.394.13.

72. Costa, G.; Vizzotto, G. Fruit Thinning of Peach Trees. Plant Growth Regulation 2000, 31, 113-119, doi:10.1023/A:1006387605042.

73. Lenahan, O.; Whiting, M.; Elfving, D. Gibberellic Acid Inhibits Floral Bud Induction and Improves 'Bing' Sweet Cherry Fruit Quality. HortScience: a publication of the American Society for Horticultural Science 2006, 41(3), 654-659, doi:10.21273/HORTSCI.41.3.654.

74. Southwick, S.M.; Glozer, K. Reducing Flowering with Gibberellins to Increase Fruit Size in Stone Fruit Trees: Applications and Implications in Fruit Production. HortTechnology 2000, 10, 744-751, doi:10.21273/HORTTECH.10.4.744.

75. Lenahan, O.M.; Whiting, M.D. Physiological and Horticultural Effects of Sweet Cherry Chemical Blossom Thinners. HortScience 2006, 41, 1547-1551, doi:10.21273/HORTSCI.41.7.1547.

76. Lenahan, O.M.; Whiting, M.D. Chemical Thinners Reduce Sweet Cherry Net CO2 Exchange, Stomatal Conductance and Chlorophyll Fluorescence. In Proceedings of the V International Cherry Symposium 795; Acta Hort., 2005; Vol. 795, pp. 681-684.

77. Andersen, C.C., and Robert L. Variable Fruit Set in Self-Fertile Sweet Cherry. Can. J. Plant Sci. 2001, 81, 753-760, doi:10.4141/P00-161.

78. Bound, S.A.; Close, D.C.; Quentin, A.G.; Measham, P.F.; Whiting, M.D. Crop Load and Time of Thinning Interact to Affect Fruit Quality in Sweet Cherry. Journal of Agricultural Science 2013, 5.

79. Landi, M.; Massai, R.; Remorini, D. Effect of Rootstock and Manual Floral Bud Thinning on Organoleptical and Nutraceutical Properties of Sweet Cherry (Prunus Avium L.) Cv 'Lapins.' 2014, 58, 335-351, doi:10.12871/0021857201444. 
80. Choi, C. Fruit Growth Responses in "Hedelfingen" Sweet Cherry with Five Rootstock Cultivars, Thinning, and Irrigation; Cornell University, January, 1995;

81. Bielicki, P.; Rozpara, E. Growth and Yield of 'Kordia'Sweet Cherry Trees with Various Rootstock and Interstem Combinations. Journal of Fruit and Ornamental Plant Research 2010, 18, 45-50.

82. Lanauskas, J.; Uselis, N.; Kviklys, D.; Kviklienè, N.; Buskienè, L. Rootstock Effect on the Performance of Sweet Cherry Cv. Lapins. Horticultural Science 2012, 39, 55-60.

83. Vercammen, J. Dwarfing Rootstocks for Sweet Cherries. Acta Hortic. 2004, 307-311, doi:10.17660/ActaHortic.2004.658.44.

84. Vercammen, J.; Van Daele, G.; Vanrykel, T. Use of Gisela 5 for Sweet Cherries. Sodininkystè ir daržininkystė 2006, $25,218-223$.

85. Blažková, J.; Hlušičková, I. Results of an Orchard Trial with New Clonal Sweet Cherry Rootstocks Established at Holovousy and Evaluated in the Stage of Full Cropping. Hort. Sci. (Prague) 2008, 34, 54-64, doi:10.17221/1849-HORTSCI.

86. Sansavini, S.; Lugli, S. Performance of V-Trained Cherry Orchard with New Dwarf Rootstocks. Acta Hortic. 1998, 265-278, doi:10.17660/ActaHortic.1998.468.31.

87. Franken-Bembenek, S.; Gruppe, W. Effect of Different Hybrid Rootstocks on Growth and Yielding Characters of Sweet Cherries. Acta Hortic. 1985, 219-226, doi:10.17660/ActaHortic.1985.169.30.

88. Milić, B.; Kalajdžić, J.; Keserović, Z.; Magazin, N.; Ognjanov, V.; Miodragović, M.; Popara, G. Early Performance of Four Sweet Cherry Cultivars Grafted on Gisela 5 and Colt Rootstocks in a High Density Growing System. asphc 2019, 18, 99-108, doi:10.24326/asphc.2019.1.10.

89. Kappel, F.; Lichou, J. Flowering and Fruiting of 'Burlat' Sweet Cherry on Size-Controlling Rootstock. HortSci 1994, 29, 611-612, doi:10.21273/HORTSCI.29.6.611.

90. Bieniek, A.; Kawecki, Z.; Kopytowski, J.; Zielenkiewicz, J. Yielding and Fruit Quality of Lithuanian Sweet Cherry Cultivars Grown under the Climatic and Soil Conditions of Warmia. Folia Horticulturae 2011, 23, 101-106, doi:10.2478/v10245-011-0015-4.

91. Szpadzik, E.; Krupa, T.; Niemiec, W.; Jadczuk-Tobjasz, E. Yielding and Fruit Quality of Selected Sweet Cherry (Prunus Avium) Cultivars in the Conditions of Central Poland. Acta Scientiarum 2019, 18, 117-126.

92. Link, H. Significance of Flower and Fruit Thinning on Fruit Quality. Plant Growth Regulation 2000, 31, 17-26, doi:10.1023/A:1006334110068.

93. Tukey, H.B.; Young, J.O. Histological Study of the Developing Fruit of the Sour Cherry. Botanical Gazette 1939, 100, 723-749, doi:10.1086/334827.

94. Łysiak, G. The Sum of Active Temperatures as a Method of Determining the Optimum Harvest Date of 'Sampion' and 'Ligol' Apple Cultivars. Acta Scientiarum Polonorum-Hortorum Cultus 2012, 11, 3-13.

95. Measham, P.F.; Bound, S.A.; Gracie, A.J.; Wilson, S.J. Crop Load Manipulation and Fruit Cracking in Sweet Cherry (Prunus Avium L.). Advances in Horticultural Science 2012, 26, 25-31.

96. Kappel, F.; Fisher-Fleming, B.; Hogue, E. Fruit Characteristics and Sensory Attributes of an Ideal Sweet Cherry. HortSci 1996, 31, 443-446, doi:10.21273/HORTSCI.31.3.443.

97. Whiting, M.D.; Lang, G.A. Effects of Leaf Area Removal on Sweet Cherry Vegetative Growth and Fruit Quality. Acta Hortic. 2004, 467-472, doi:10.17660/ActaHortic.2004.636.57.

98. Usenik, V.; Orazem, P.; Stampar, F. Low Leaf to Fruit Ratio Delays Fruit Maturity of 'Lapins' Sweet Cherry on Gisela 5. Scientia Horticulturae 2010, 126, 33-36, doi:10.1016/j.scienta.2010.06.008. 
99. Whiting, M.D.; Lang, G.A. 'Bing' Sweet Cherry on the Dwarfing Rootstock 'Gisela 5': Thinning Affects Fruit Quality and Vegetative Growth but Not Net CO2 Exchange. J. Amer.Soc. Hort. Sci. 2004, 129, 407-415, doi:10.21273/JASHS.129.3.0407.

100. Schoedl-Hummel, K.; Modl, P.; Forneck, A. Flower Thinning in Sweet Cherry (Prunus Avium L.): A First Year Field Study. Mitteilungen Klosterneuburg 2007, 57, 176-179.

101. Cittadini, E.D.; de Ridder, N.; Rodríguez, M.J.; van Keulen, H.; Peri, P.L. Fruit Dry Weight and Quality of "Bing” Sweet Cherries Grown Without Source Limitations. Acta Hortic. 2008, 639-644, doi:10.17660/ActaHortic.2008.795.99.

102. Looney, N.E. Effects of Crop Reduction, Gibberellin Sprays and Summer Pruning on Vegetative Growth, Yield, and Quality of Sweet Cherries. Manipulation of fruiting 1989, 47, 39-50.

103. Kappel, F. Partitioning of Above-Ground Dry Matter in 'Lambert' Sweet Cherry Trees with or without Fruit. J. Amer. Soc. Hort. Sci. 1991, 116, 201-205.

104. Roper, T.R.; Keller, J.D.; Loescher, W.H.; Rom, C.R. Photosynthesis and Carbohydrate Partitioning in Sweet Cherry: Fruiting Effects. Physiol Plant 1988, 72, 42-47, doi:10.1111/j.1399-3054.1988.tb06620.x.

105. Claverie, J.; Lauri, P.E. Extinction Training of Sweet Cherries in France - Appraisal after Six Years. Acta Hortic. 2005, 367-372, doi:10.17660/ActaHortic.2005.667.52.

106. Nagy, P.; Thurzó, S.; Racskó, J.; Nyéki, J.; Soltész, M.; Szabó, Z. Effect of Different Flower Thinning Techniques on Annual Fluctuation of Macro and Micronutrients in Sweet Cherries. International Journal of Horticultural Science 2007, 13, 87-90.

107. Farquhar, G.D.; Sharkey, T.D. Stomatal Conductance and Photosynthesis. Annual review of plant physiology 1982, $33,317-345$.

108. Krause, G.H.; Weis, E. Chlorophyll Fluorescence as a Tool in Plant Physiology. Photosynth Res 1984, 5, 139-157, doi:10.1007/BF00028527.

109. Sams, C.E.; Flore, J.A. The Influence of Age, Position, and Environmental Variables on Net Photosynthetic Rate of Sour Cherry Leaves. J. AM. SOC. HORTIC. SCI. 1982, 107, 339-344.

110. Percival, G.C.; Henderson, A. The Influence of De-Icing Salts on Growth and Leaf Photochemistry of Seven Urban Tree Species. Arboricultural Journal 2002, 26, 23-41, doi:10.1080/03071375.2002.9747316.

111. Pietrini, F.; Chaudhuri, D.; Thapliyal, A.P.; Massacci, A. Analysis of Chlorophyll Fluorescence Transients in Mandarin Leaves during a Photo-Oxidative Cold Shock and Recovery. Agriculture, Ecosystems E Environment 2005, 106, 189-198, doi:10.1016/j.agee.2004.10.007.

112. Roper, T.R.; Kennedy, R.A. Photosynthetic Characteristics during Leaf Development in Bing Sweet Cherry. Journal of the American Society for Horticultural Science 1986, 111, 938-941.

113. Bound, S.A.; Close, D.C.; Jones, J.E.; Whiting, M.D. Improving Fruit Set of "Kordia" and "Regina" Sweet Cherry with Avg. Acta Hortic. 2014, 285-292, doi:10.17660/ActaHortic.2014.1042.34.

114. Fallahi, E.; Fallahi, B.; McFerson, J.R.; Byers, R.E.; Ebel, R.C.; Boozer, R.T.; Pitts, J.; Wilkins, B.S. Tergitol-TMN-6 Surfactant Is an Effective Blossom Thinner for Stone Fruits. HortSci 2006, 41, 1243-1248, doi:10.21273/HORTSCI.41.5.1243.

115. Fallahi, E.; Colt, M.; Mohan, S.K.; Fellman, J. Effects of Hydrogen Cyanamide on Stone Fruit Thinning. HortSci 1990, 25, 1122a-11122, doi:10.21273/HORTSCI.25.9.1122a.

116. Fallahi, E. Applications of Endothalic Acid, Pelargonic Acid, and Hydrogen Cyanamide for Blossom Thinning in Apple and Peach. horttech 1997, 7, 395-399, doi:10.21273/HORTTECH.7.4.395. 
117. Ionescu, I.A.; López-Ortega, G.; Burow, M.; Bayo-Canha, A.; Junge, A.; Gericke, O.; Møller, B.L.; Sánchez-Pérez, R. Transcriptome and Metabolite Changes during Hydrogen Cyanamide-Induced Floral Bud Break in Sweet Cherry. Front. Plant Sci. 2017, 8, 1233, doi:10.3389/fpls.2017.01233.

118. Lewis, K.M. Labor Management in Modern Orchards and Opportunities for Mechanization Available online: https://apal.org.au/wp-content/uploads/2019/09/Karen-Lewis-Future-Orchards-Mar-2015.pdf.

119. Schupp, J.; Lewis, K.; Baugher, T.A.; Remcheck, J. Mechanized thinning for labor efficient tree fruit cropload management; 2010;

120. Innovative Technologies for Thinning of Fruit - PENNSYLVANIA STATE UNIVERSITY Available online: https://reeis.usda.gov/web/crisprojectpages/0215926-innovative-technologies-for-thinning-of-fruit.html (accessed on 19 December 2021).

121. Meng Wang; Qin Zhang; Karen M Lewis End-Effector Performance Evaluation of a Hand-Held Mechanical Bloom Thinning Device. In Proceedings of the 2012 Dallas, Texas, July 29 - August 1, 2012; American Society of Agricultural and Biological Engineers, 2012. 